Pakistan Journal of Education

Vol.36, No.2, 2019, 1-22

\title{
The Discursive Constructions in School: A Qualitative Assessment of Value Conflicts between School Ethos and Everyday Life
}

\author{
Afia Misri* \\ Muhammad Bilal $^{* *}$
}

\begin{abstract}
The debate of quality education in Pakistan revolves around three basic systems of education - Elite English Medium Education System, State Urdu Medium Education System and Madrassa Education System. However, the history and discourse of education planning and development in Pakistan largely ignores the aspects of school socialization when addressing the development issues of children. While focusing on the psychological and cultural incongruences in the school socialization experiences of children, this paper asks that what are the major realms where school going children experience conflicts between the school ethos and real-life practices? The ethnographic study was conducted in Chakwal city, located in Punjab Province, involving participant observation in private and public schools. In-depth interviews were also conducted to acquire a holistic understanding of emerging trends of school ethos among students. The sample was selected through purposive sampling which includes students, parents and teachers belonging to different educational levels and diverse socio-economic backgrounds. The findings suggest that the incongruence between school socialization and what children experience in wider society engender conflicting worldviews eventually creating everyday value-conflicts and identity crisis among children.
\end{abstract}

Keywords: school ethos, socialization, value-conflict, identity, Pakistan

\footnotetext{
Lecturer, Department of Humanities, Air University, Islamabad, Pakistan.

** Corresponding Author: Head, Department of Anthropology, Fatima Jinnah Women

University, Rawalpindi, Pakistan, Email: anth.fjwu@gmail.com
} 


\section{Introduction}

School, as the primary agent of socialization, prepares students to perform meaningful roles in the society. School socialization is imperative in constituting a social-self and makes substantial contribution towards students' general well-being. Students learn various academic, social and emotional skills in schools aiming to transmute them into accomplished individuals(Noble, Wyatt, McGrath, Roffey \& Rowling, 2008). Several studies in the domain of school psychology (Abbasi, 2016; Johnson B., 2008; Lucktong, Salisbury \& Chamratrithirong, 2018; Oldfield, Stevenson, Ortiz \& Haley, 2018) have suggested that salubrious school socialization experiences count for positive identity development, improved social performance and promote resilience towards psychosocial difficulties. Since the schooling phase of a child is characterized by the development of new physical, cognitive, and social abilities (Schunk \& Meece, 2006), a child is more vulnerable to the developmental crises (Kroger, 2004). The domain of educational psychology needs major thrust in the developing countries like Pakistan. The profound changes in the education system of Pakistan and sociopolitical instabilities have brought a major shift in the nature of school socialization experiences of children as indicated in the recent studies conducted to explore the role of schools as a principal agent of socialization (Javed, Kausar \& Khan, 2014; Hassan, Farooq, Akhtar \& Parveen, 2017; Malik, 2013; Malik, Fatima \& Chaudhry, 2017). Moreover, the existence of qualitative and quantitative differences in the multiple education systems of Pakistan provides diverse experiences of socialization that tend to influence the psycho-social development of children in a distinct manner (Ahmed, Shaukat \& Abiodullah, 2009). Consequently, the debate on school ethos arises as a significant concern which exposes the younger generation to a variety of psychological conflicts and social enigmas (Rehman \& Khan, 2011).

The historical circumstances played a major role in creating the challenge of socialization paradox at schools. Pakistan inherited a meager and divided educational system from the colonials (Aamer, 2009). Educational planning and policies have remained incongruent with the local needs as well as problems of policy implementation have been posing a daunting challenge for the educational landscape of the country (Rehman \& Khan, 2011). All Pakistan Education Conference was the first effort which was intended to stabilize the education sector of Pakistan. In 1948, the Central Advisory Board of Education was established for the discussion of educational problems (Peshkin, 1963). In 1972, the government of Pakistan took a step to nationalize the private 
education institutions, restating a commitment to universal free education (Parveen, 2008). Education policy 1979 gained much significance in the educational discourses because of its significant contribution to bringing an ideological shift in the social cognitive makeup of the local people through Islamic ideology and cultural development (Shah, 2012). Later, Afghan war and succeeding wave of Islamization (1979-1989) also left a great influence on the education landscape of Pakistan leading to major vicissitudes in the curriculum design and formulation (Aamer, 2009). The era of the 1990s is referred to as a period of globalization and neoliberalism which influenced the socio-cultural and political landscapes of most of the countries and put a central emphasis on education and technology. Subsequently, active encouragement of education privatization was observed during the 1990sin Pakistan (Andrabi, Das \& Khwaja, 2008). It is for the same reason that the national education policy 1998-2010 encouraged the private-public partnership schemes for establishing schools in rural areas.

However, none of the policies to stabilize the education sector in Pakistan proved successful due to manifold political and social instabilities (Ahmad, Rauf, Imdadullah \& Zeb, 2012). One of the rising ambiguities was related to the language and medium of instruction in Pakistani schools which turned the inclination of the majority of people towards English medium private schooling. Now the country holds multiple education systems with long rooted disparities where private schools are believed to cause social division and value conflicts (Rehman \& Khan, 2011). In such a scenario, school socialization has become a significant denominator that could create a stable or unbalanced relation between an individual and broader social system.

Also, the role of schools and teachers become cardinal to prevent ideological bewilderment and value crises(Akram \& Rana, 2013). The growth of private and public schooling raises certain concerns regarding the qualitative and quantitative differences of school climate and culture. A growing body of researches (Awan \& Zia, 2015; Iqbal, 2012; Malik, 2015) has focused on the comparative strengths and weaknesses of private and public sectors of education in Pakistan. However, less attention has been paid to the diversity in the prevalent socialization patterns of private and public schools and to discern its impacts on the development of social ethos and identity development among school going children.

The current study employed the ecological theory of human development proposed by Urie Bronfenbrenner in the field of educational psychology as the theoretical framework. According to this 
theory, the different types of environmental systems influence child development. These systems include the micro system, the mesosystem, the exosystem, the macro system, and the chronosystem (Bronfenbrenner, 1975).This theory is applied to the current research to comprehend the role that schools, being a proximal structure of Microsystem, play in the formulation of self-concept through the process of socialization. Schools are considered responsible for inculcating the basic ideologies and socio-cultural norms and build belief system about the outer world. These school-induced values may or may not come into conflict with the broader social practices. The paradoxes in school ethos create conflict of values, interest and style. In face of such crises situation, the stability of a child's psychological and social health engenders a serious challenge for grooming a healthy and productive personality. Accordingly, this study asks certain questions such as what are the major areas where school going children experience conflicts between the school ethos and real-life practices? And how these incongruities influence the socio-emotional development of children?

\section{Research Methodology}

This research is based on qualitative design whereby different qualitative research methods and techniques have been employed to gain an in-depth understanding of the issue at hand. A substantial increase in the use of qualitative research methodologies has been seen in the field of educational research (Delamont, 2012; Eriksson, Boistrup \& Thornberg, 2018; Torrance, 2010). Since 1980s, counseling psychology started to use discursive domain of psychology as a qualitative approach to understand the psychological constructs and psycho-social phenomena through language (Molder, 2015; Potter \& Wetherell, 1987; Willig, 2008, Winslade, 2005). The current paper uses this very epistemological foundation of discursive tradition while using the qualitative methodology to gain insight of how children construct their social realities and what conflict they face during their school socialization period (Martínez - Guzmán, Stecher \& Íñiguez Rueda, 2016, Winslade, 2005).The use of social discourses as a qualitative method received immense focus in educational arena because children enter into the school during their developmental phase- a stage of cognitive, social and emotional development, a stage where meanings are established and identity narratives are formed (Alao, 1991; Egbo, 2015). 


\section{Population, Sampling and Locale}

The research was carried out between February 15, 2017, and July 30, 2017, in Council City 1 and 2 of Chakwal. The participant observation was conducted in nine schools out of which three were government-run schools and six were private schools. As the strength of students in government schools was huge than private schools, therefore, only three schools from government sector were selected.

Purposive sampling was used for the selection of private and public schools. Purposive sampling is a type of non - probability sampling which involves the selection of participants based on a predetermined criterion which relates to the study questions and does not aim to provide the equal chances to all the participants in order to generalize the findings (Saumure \& Given, 2008). In this research, purposive sampling has been used to select schools and participants, to address the research questions. Among private schools, only those schools were chosen which were considered as elite schools of the community. The reason behind the inclusion of elite private schools was the existence of major qualitative differences between elite private and public schools that enabled to grasp richer information regarding the diverse socialization environment.

The population of the study consists of teachers, students and parents of school going children belonging to diverse educational and socio-economic backgrounds. The total number of students for in-depth Interviews was 40 selected both from government and private schools respectively. This sample includes 20 male and 20 female students while 10 male students were selected from private schools and 10 from the government schools. The same ratio was followed while selecting the female students. The number of teachers interviewed in this study was 18 including 9 from the private schools (4 males and 5 female teachers) and the same number was chosen from the government schools (4 females and 5 males). In regard to the selection of parents, 15 fathers and 15 mothers were interviewed in order to grasp the perspective of both parents belonging to diverse socio-economic and educational backgrounds to obtain the holistic perspectives of the parents. Apart from in-depth interviews, a large number of sample was approached during participant observation in schools, which included interactions with almost 60 teachers, $150-200$ students and $30-50$ parents who visited schools during parent-teachers meeting or to attend different school functions. 


\section{Instrumentation}

In order to ensure the reliability and validity of the data, the current research deployed methodological triangulation using diverse methods including participant observation and in-depth interviews. Methodological triangulation is a method to attain congruency in findings to strengthen the validity of the study (Bekhet \& Zauszniewski, 2012).

\section{Participant Observation}

Participant observation is the key method of ethnography (Morgan - Trimmer \& Wood, 2016). Much of the qualitative research in the field of educational and social psychology regard participant observation as the effective way to better understand the socio-cultural context, processes, social relationships, patterns of interactions and their continuities with time (Højholt \& Kousholt, 2014; Jorgensen, 1989). According to Kawulich (2005), participant observation proves to be useful in gaining an in-depth understanding of the physical, social, cultural, and economic contexts of the participants; their interrelationships, ideas, norms, events; their behaviors and activities that is what they do, how often, and with whom (see also Jorgensen, 2015).In order to develop a qualitative understanding of value conflicts and school ethos, participant observation was conducted in various schools for five months. In each school at least two weeks were spent.The focus of observation was to understand the children's socialization processes and experiences in order to understand their value construction in the school environment as well the conflict of these values with the broader social system. The aim was achieved while participating in various activities in formal and informal patterns of student and teachers' interactions at various places in schools while participating in class discussions, delivering lectures as a teacher, interactions with the teachers in staff room settings, participating in the sports competition week and farewell events along with the students. Besides, the native status of researchers enabled to observe students in their daily interactions at informal sitesincludingschoolvans and social gatherings. 


\section{In-depth interviews}

Interviewing is an extensively used method in qualitative research in general and educational research in particular (Banister, Parker, 2005; Partington, 2001; Willig, 2008). In-depth interviews have been conducted to acquire more comprehensive data regarding the school ethos being promoted in the school students and how school ethos come in conflict with their experience to the outer world. In-depth interviews give useful data about the perspectives, opinions and experiences of individual participants (Boyce \& Neale, 2006).

In-depth interviews were also conducted along with participant observation whereby three interview guides were developed in English language. These interview guides were translated into Urdu after a pilot study for enhancing the comprehension of the subject. The translation of the interview guide was based on the local understanding of the participants and included the terms, which were comprehendible for the participants. These interview guides were constructed to understand the impact of school climate on the socialization experiences, ethos development and social attitudes in a more inclusive way by indulging the participants in a variety of questions addressing different aspects of the topic. These topics cover the three basic objectives of the study: to see the development of social values in private and public - school students, to explore the kind of value conflicts they face in real life and to analyse the psychological and social impact of these value conflicts on student's socio -cultural attitudes.

Field jottings were taken to record the responses, which were converted to field notes afterward. Twenty-three interviews were conducted with students, parents and teachers of private and government schools. Each interview lasted for about 45 to 90 minutes. Most of the interviews were taken in Urdu while a few interviews were also conducted in Punjabi language as per the respondents' comprehension and comfort. The interviews in elite private schools were conducted in Urdu and few in Punjabi language as these schools are located in Chakwal, a traditional region, where the languages of everyday 
communication are Urdu and Punjabi and inhabitants prefer to explain their perspectives in these languages.

\section{Procedure}

The process of actual data collection and fieldwork was started by seeking permission from the school authorities and building rapport which is crucial for gaining rich qualitative insights. It helps the respondents to open up, enabling the researcher and the participant to develop a relationship of trust, empathy and mutual respect thus venturing a safe and comfortable environment to the participant for yielding open and in-depth communication (Partington, 2001). The topic was explained to the participants to clear out their ambiguities and queries about the study and made them aware of the process they are becoming a part of Participant's consent was taken both verbally and in written form.

After the fieldwork, thematic analysis was used to analyze the data. In thematic analysis, several themes are identified based on coding and labelling various emerging patterns of the data to elaborate the certain configurations regarding the research questions and to explain the possible theoretical and empirical reasoning for these findings (Alhojailan, 2012; Braun \& Clarke, 2006)

\section{Results and Discussion}

The following discussion presents the major realms where school going children experience conflicts between the school ethos and reallife practices. It further attempts to illustrate how the clash of different social experiences between school and home hinders the social development of a child.

\section{Religious Tolerance and Socialization Discourses}

The debate of religious ethos involves two significant dimensions which are pertinent in Pakistani society - living one's personal life according to religious teachings and how an individual reacts towards opposite religious perspectives. The findings reveal that 
though school authorities claim to inculcate religious tolerance through various discourses, the socialization at homes and in wider society seems to contradict the school learning in various respects. Students reported that they face a contradictory situation in the outer world. Students argued that at schools, they are taught to keep good relations with people of opposite sects, their family discourses and religious teachers label opposite sect as non-believers and infidels. This was highlighted by one of the students studying in class eighth who asserted:

Schoolteachers say that we all are Muslims but my father says that other sects are apostate. I do not understand whom to follow.

Several psychological studies suggest that religious infusion, cognitive rigidity and religious prejudice against the opposite religious group intensify intergroup conflict (Neuberg et al., 2014; Saroglou, 2016). However, a higher level of religious and sectarian conflicts is found to be associated with greater symptoms of cognitive disruption, psychological conflict and anxiety (et al., 2009 Goeke-Morey). According to one of the students named Ali studying in class tenth at The Educators:

My father is a Barelvi $i^{i}$ but my brother is a Deobandi ${ }^{i i}$. Both of them do not go to the same mosques for offering prayer. I do not understand where should I go?

This sect-based division of mosques in Chakwal holds its grounds in the persisting ideological differences which exist among the sects in the social atmosphere of Pakistan. Barelvis, Deobandis and Ahl-e-Hadith ${ }^{i i i}$ have separate mosques exercising their sectarian identity. One common example of the enforcement of sectarian identity through mosques can be observed during the Friday sermons. It is a common practice to denounce the other sects in order to prove them iniquitous and perverse. Such manifestations of religious abhorrence develop a state of confusion among children where they face conflict in school ethos and real-life experiences. During the fieldwork, children of both private and government schools reported that teachers tell them that all Muslims are brothers and mosque is a place of worship for all Muslims. One of the students named Shahrukh, who is studying in class tenth at Chakwal Grammar School, asserted that now the House of Allah (mosque) is 
divided by the followers of various sects. He put a question that if all Muslims believe in Allah, then why during the sermons foul and coarse language is used against other sects?

Conflicts in religious ethos also come to the surface of child's experiences when some parents teach their children to prefer a friend from their own sect. In this regard, several children reported during the fieldwork that their parents strictly forbade them from eating Niyaz brought by their class fellows as well as are not allowed to attend Ashura Majlis $^{v}$ in their neighbourhood. Though differences between one's sect and other religious minorities are not encouraged in school settings in order to create harmony and tolerant environment, sectarian tensions and hatred proliferated through family socialization and other social institutions are engendering an intolerant attitude among the students. One of the example in this regard are the views of some of the Sunni students who expressed that attending the funeral prayer of a person belonging to Shia ${ }^{v i}$ sect is proscribed in Islam.

Religious discourses in Pakistani society at large constitute certain conflicts with the school ethos giving rise to incongruence and psychological discord (Mahsood, 2017). In Chakwal, these conflicts are exhibited in religious addresses, sermons and inter-sect exchange of speeches by local clerics and religious leaders at various occasions such as Majalis in Muharram ${ }^{\mathrm{vii}}$, Milad ceremonies (a ceremony held to commemorate the birth of Holy Prophet (PBUH) and sect-related orations at various religious gatherings. According to Sewag (2016), hatred for opposite sects and clerics' decrees of calling other sects as infidels are interrelated and leads to the practice of killing in the name of blasphemy. Several incidents in Pakistan are prime depiction of such killings. Mashal Khan's murder in Abdul Wali Khan University Mardan by his fellow students in 2017 is a recent incident where he was accused of publishing blasphemous content. Furthermore, fanatical speeches, posters and handbills produced by the various sects provoke their blind followers' thinking pattern to the extent that they consider their sect as one complete version of Islam and as the only path to get to heaven. 
Such sermons and teachings not only defies what students learn in schools but also create sectarian xenophobia (Shah, 2014).

The history of sectarian tensions, conflicts and discrepancies in Pakistan is not new but it does not carry the same consequences as before. Now, the religious processions and rallies in Chakwal taken out at various points like $12^{\text {th }}$ Rabi-ul-Awwal ${ }^{\text {viii }}$ and $9^{\text {th }}$ and $10^{\text {th }}$ Muharram are not mere religious expressions. Instead, these processions are considered as a way to show one's power against the other sect. Children, being part of these gatherings grow up raising such slogans that contradict the school preaching of brotherhood and forbearance thus creating psychological tension and disharmony in the schemas of children.

Religious intolerance was further channelled through the Islamization policy of General Zia-ul-Haq who for the legitimacy of his government vehemently encouraged the militancy in the country. The religious intolerance introduced during the decade of the 1980s eventually fueled the sectarian conflicts in the country.

In Pakistan, sectarian rift and violence have resulted in periodic attacks on schools considering school education as forbidden in Islam. The current research has shown that the social propensity of religious intolerance has clenched the educational institutes of Chakwal where students are confused not only about their own religious identity but also skeptical of those students who belong to a different sect.

\section{Respect and Justice: Discursive Construction and Conflicts}

Education is an unassailable and primordial instrument to construct a just and judicious society. Educational institutions are responsible for countering discrimination and to disseminate a culture of respect, equity andequality among students. Children studying in government and private schools in Chakwal exhibited bewilderment when they were asked what they think about the values of respect and justice in the society.

One of the female students spontaneously replied in this regard that his family treats wealthy relatives who reside in a posh area with great respect and protocol whereas poor relatives do not receive such 
veneration. She disconcertingly raised her trepidation that though they are being taught the values of respect and equality at schools, but how to explain what happens in her home?

Teachers of both private and government schools said that they try to teach children the values of respect, equality and justice but they have no control over what happens in a student's homes. One of the male teachers while explaining this further said that housemaids are disgraced and insulted badly in front of the children. Such practices create psychological confusion and disturbance where children face the discrepancies in the teachings and practices during their socialization. This conflict also exists in schools where teachers are seen to impart values of respect and equality. However, the social practices in school settings oppose the teachings. While supporting this point, one of the students named Farhan asserted that a child from wealthy background is treated above rules and regulations. He expressed that such discrepancies hurt and cause disturbance. According to a teacher of a government school, it is ironical that teachers including herself teach children the lessons of truth and justice and then make them a part of this system where rich and poor have a separate set of values. Similarly, one of the female private school teachers proclaimed that from assembly conduction to the award of the gold medal, students from influential background have reserved rights. Such students have also been observed while threatening the teacher which is neglected by the school authorities because of their power and influence. The above responses also reflect the conflicts in justice values for those who belong to the lower classes and are taught the lessons of hard work and honesty to become successful in life. Consequently, these conflicts become a source of psychological distress and a state of confusion arises where the terms like justice, fairness and equality are mingled with those who are influential, powerful and rich. These behaviours are not only encouraged by the family environment, the school system in Pakistan also participates in shaping such kind of responses and perceptions. According to a father named Faisal, there is corruption in all schools. He argued further that teachers provide opportunities to only those students 
who are toppers and their favourite ones. A similar response was affirmed by a private school teacher named Afzal who proclaimed:

Only those students win gold medal who either come from influential families or flatter around teachers.

\section{Language and Identity: Understanding Socialization Landscape}

Pakistan is a linguistically diverse and rich country. However, this linguistic diversity is not being promoted by the state institutions and specifically the education system of Pakistan (Coleman \& Capstick, 2012). Considering the historio-political significance of English and other regional languages in post-colonial Pakistan, there are many questions which need attention in this regard, as to which language represent the ethos of Pakistani society? Is it English, Urdu or the local languages which include a variety of vernacular languages - Punjabi, Sindhi, Balochi, Saraiki or Pushto? Cognizant of English language's dominant position, most of the high-end private English medium schools in Pakistan in general and Chakwal in particular emphasize on English and discourage the use of local languages - Punjabi or Pushto or any other language in an effort to restrict the children to speak English. The one who speaks Punjabi is considered as 'Paendu' (Rahman, 2006) and one of the recent example in this regard is a notification released in 2016 from an elite private school Beacon House School System, Sahiwal Campus stating the discipline policy of the school according to which Punjabi is considered as a foul language and prohibited in or out of school premises(Samaa, 2016).

The findings of the study reveal certain discrepancies which students face in everyday life interactions. According to one of the private school students, Urdu is the national language, but no one likes to speak Urdu in her circle which is strange. A father named Faisal gave similar response:

Who gives job without English? Our languages are Punjabi and Urdu but the one who speaks English is highly appreciated. If you are not good at speaking English, teachers do not give good grades. 
Such responses depict that English language is considered as a key to upward social mobility. Employment opportunities and good life style are thought to be based upon the criteria of speaking English and not on the degree of honesty and hard work a person puts in. On one side, children are taught to work hard to succeed, on the other side, success is associated with English language creating a state of confusion and indulging children in the ideological war. Such kind of mindset was manifested by one of the students of class nine named Fatima who is studying in a government school. She argued that her mother argues that there is no future without English. She further strengthened her viewpoint by exemplifying that her class fellow gets teachers' attention and good grades because of her fluent English. In line with her experiences, she inquired that what is the worth of hard work and dedication? Fieldwork observations also underscore some discrepancies in the daily life interactions of children when their friends, parents and teachers prefer to speak English language to look western, modern and trendy. Kashan a private school student of class five proclaimed:

We are told at home when you meet others, say Aslam o Alaikum but here in school, our class teacher says that you have to say good morning when you come here.

This attitude is common particularly among the students of the elite private school who greet each other with words like 'Hi', 'Good morning', 'Hey' instead of saying 'Aslam o Alaikum' considering it traditional and an out-dated manner. In an effort to gain western trendy cool look in an Asian society like Pakistan, these words differentiate them from other members of the society giving them superiority and domination. This creates identity confusion in some students where they find themselves in the middle and use both the Islamic way and western way in their greetings to find approval and acceptance in their circle. Even some parents also promote English in their children as a symbol of progress and high class. 


\section{Conclusion}

The framework of socialization in Chakwal substantiates the argument that the value system embedded in both private and government schools is at odds with those ethos which define the everyday discourse of life. Educational attainment is deemed as a primary constituent of socioeconomic development and long-run prosperity of nations; however, the contradictory lived experiences of children in schools and wider society poses a major question that how individuals with baffled identity development will contribute to the country's social and economic prosperity? In the struggle to seek a balance between contradictory values, students often face a situation of crisis which makes them vulnerable to a variety of psychological and social issues. The rising schism between different sects of Islam, exposure to western trends and undermining one's language are note worthy zones creating conflicting situation for children to the extent where they face a misalliance between indigenous value discourses and express a state of psychological wobbliness. The on-going scenario of ethos conflict has been creating severe identity predicaments among students, however, socialization conflicts between school environment and the general social environment have not received much scholarly attention from educationists and social scientists. This neglect has been seriously enhancing the challenge of identity development among Pakistani students. The current study puts forth certain interventional implications. Both parents and schools need to work collaboratively and consistently for constructive development of a child in order to save them from identity crunches. Also, educational reforms need to undergo significant changes to meet the value gulf between private and government schools as two divergent school environments impart diverse and often paradoxical worldviews challenging the social cohesion of the country.

i. Barelvi is a sub-sect of Sunni Muslims who follow Hanafi school of Islamic jurisprudence and typically known for their veneration of saints and admiration of Sufi Islam.

ii. A sub-sect of Sunni Muslims who, like Barelvi Muslims, follow Hanafi school of Islamic jurisprudence, however, believe in the strict interpretation of Islamic 
practices and reject certain Barelvi beliefs considering them innovations in Islam.

iii. Ahl-e-Hadith do not follow Imaams in fiqh(Islamic jurisprudence)

iv. Niyaz or Nazr refers to the food which is offered in order to seek the intercession from saints or a religious figure believing that that they would help the asker in his/her problems and Aakhirah (afterlife).

v. Ashura Majlis is a religious gathering which is held to mourn Hazrat Imam Hussain (R.A.), the grandson of Prophet (PBUH)

vi. A sect of Islam which primarily follows Ja'fari school of thought and believes that Hazrat Ali (R.A.) is the first legitimate successor of Holy Prophet (PBUH) and do not recognize the authority of first three caliphs.

vii During this month mostly Shia Muslims, mourn the martyrdom of Imam Hussain (R.A), the grandson of Prophet Muhammad (PBUH).

vii $12^{\text {th }}$ Rabi-ul-Awwal is the accepted date among most of the Sunni scholars as the birthday of Prophet (PBUH).

ix The term Paendu (or villager) has various connotations. It is often used for an old-fashioned individual. 


\section{References}

Aamer, M. (2009). Existing education system of Pakistan: Psycho-social and socio-economic effects. NDU Journal, 13-31.

Abbasi, N. (2016). Adolescent identity formation and the school environment. In K. Fisher (Ed.), The translational design of schools An evidence-based approach to aligning pedagogy and learning environments (83-103). Rotterdam: Sense

Ahmad, I., Rauf, M., Imdadullah, \& Zeb, A. (2012). Implementation gaps in educational policies of Pakistan: Critical analysis of problems and way forward. International Journal of Humanities and Social Science, 2(21), 240-245.

Ahmed, R. N., Shaukat, S., \& Abiodullah, M. (2009). Role of different educational systems in the development of moral and social traits in Pakistani students. Journal of Behavioural Sciences, 19 (1-2), 59-74.

Akram, M., \& Rana, S.A. (2013). Positive schooling and subjective wellbeing of Pakistani children. Pakistan Journal of Social and Clinical Psychology, 11(1), 42-51

Alao, A. A. (1991) Individual counseling. Ibadan: Vintage Publishers.

Alhojailan, M. I. (2012). Thematic analysis: A critical review of its process and evaluation. West East Journal of Social Sciences, 1(1), $39-47$.

Andrabi, T., Das, J., \& Khwaja, A.I. (2008). A dime a day: The possibilities and limits of private schooling in Pakistan. Comparative Education Review, 52(3), 329-355.

Awan, A. G., \& Zia, A. (2015). Comparative analysis of public and private educational institutions: A case study of district VehariPakistan. Journal of Education and Practice, 6(16), 122-130.

Bekhet, A. K., \& Zauszniewski, J.A. (2012). Methodological triangulation: An approach to understanding data. Nurse Researcher, 20 (2). 40-43. 
Banister, P., Burman, E., Parker, I., Taylor, M., \& Tindall, C. (1994). Qualitative methods in psychology. United Kingdom: Open University Press.

Boyce, C., \& Neale, P. (2006). Conducting in-depth interview: A guide for designing and conducting in-depth interviews for evaluation input. Massachusetts: Pathfinder International.

Braun, V., \& Clarke, V. (2006). Using thematic analysis in psychology. Qualitative Research in Psychology, 3(2), 77-101.

Bronfenbrenner, U. (1975). Reality and research in the ecology of human development. Proceedings of the American Philosophical Society, $119(6), 439-469$.

Coleman, H., \& Capstick, T. (2012). Language in education: Recommendations for policy and practice. Islamabad: British Council.

Delemont. S. (2012). Handbook of quantitive research in education USA: Edward Eglar Publishing.

Egbo, J.O.E. (2015). Need for guidance and counseling at the primary school level: Early intervention strategies for school children. British Journal of Education, 3(6), $1-8$

Eriksson, E., Boistrup, L. B., \& Thornberg, R. (2018). A qualitative study of primary teachers' classroom feedback rationales. Educational Research, 60(2), 189-205.

Goeke-Morey, M. C., Cummings, E. M., Ellis, K., Merrilees, C.E., Schermerhorn, A.C., Shirlow, P., \& Cairns, E. (2009). The differential impact on children of inter- and intra-community violence in Northern Ireland. Peace and Conflict: Journal of Peace Psychology, 15(4), 367-383.

Hassan, M. U., Farooq, M.S., Akhtar, M.P., \& Parveen, I. (2017). Teachers' politeness as a predictor of students' self-esteem and academic performance. Bulletin of Education and Research, 39(1), 229-243. 
Hojholt, C. \& Kousholt, D. (2014). Participant observations of children's communities-Exploring subjective aspects of social practice. Qualitative Research in Psychology, 11(3), 316-334.

Iqbal, M. (2012). Public versus private secondary schools: A qualitative comparison. Journal of Research and Reflections in Education, $6(1), 40-49$.

Javed, A., Kausar, R., \& Khan, N. (2014). Effect of school system and gender on moral values and forgiveness in Pakistani school children. Malaysian Online Journal of Educational Science, 2(4), 13-24

Johnson, B. (2008). Teacher-student relationships which promote resilience at school: A micro level analysis of students' views. British Journal of Guidance and Counselling, 36(4), 385-398.

Jorgensen, D. L. (1989). The methodology of participant observation. In Participant observation (12-25). California, United States: Sage Publications, Inc.

Jorgensen, D. L. (2015). Participant observation. In R. A. Scott, \& S. M. Kosslyn (Eds.), Emerging trends in the social and behavioural sciences (pp. 1-15). New York, NY:

Kawulich, B.B. (2005). Participant observation as a data collection method. Qualitative Social Research, 6(2), 1-28.

Kroger, J. (2004). Identity in adolescence: The balance between self and other (3rd ed.). New York, NY: Psychology Press.

Lucktong, A., Salisbury. T.T., \& Chamratrithirong, A. (2018). The impact of parental, peer and school attachment on the psychological well-being of early adolescents in Thailand. International Journal of Adolescence and Youth, 23(2). 235-249.

Mahsood, A.K. (2017). History of sectarianism in Pakistan: Implications for lasting peace. Journal of Political Sciences \& Public, 5(4), 1-7.

Malik, R. (2013). Students' personality development: Single sex versus co-educational schools in Pakistan. Asian Journal of Management Sciences and Education, 2(3), 6876. 
Malik, A. H. (2015). A comparative study of elite English-Medium Schools, Public Schools, and Islamic Madaris in contemporary Pakistan: The use of Pierre Bourdieu's Theory to understand "Inequalities in educational and occupational opportunities". Oman: Euro-Khaleeji Research and Publishing House.

Malik, M., Fatima, G., \& Chaudhry, A.H. (2017). Role of female teachers in personality development of secondary school students in Lahore: A quantitative exploration. Journal of Educational Research, 20(2), 161-169.

Martínez-Guzmán, A., Stecher, A., \& Íñiguez-Rueda, L. (2016) Discursive psychology contributions to qualitative research in social psychology: An analysis of its ethnomethodological heritage. Psicologia USP, 27(3), 510-520.

Molder, H. T. (2015). Discursive psychology. In K. Tracy, C. Ilie, \& T. Sandel (Eds.), The international encyclopedia of language and social interaction (1st ed.). Boston, MA: John Wiley \& Sons.

Morgan-Trimmer, S., \& Wood, F. (2016). Ethnographic methods for process evaluations of complex health behaviour interventions. BioMed Central, 17(232), 1-11.

Neuberg, S.L., Warner, C.M., Mistler, S.A., Berlin, A., Hill, E.D., Johnson, J.D., Schober, J. (2014). Religion and inter-group conflict. Psychological Science, 25(1), 198-206.

Noble, T., Wyatt,T., McGrath, H., Roffey, S., \& Rowling, L. (2008). Scoping study into approaches to student wellbeing: Final report (PRN 18219). Canberra, Australia: Australian Catholic University and Erebus International.

Oldfield, J., Stevenson A., Ortiz, E., \& Haley, B. (2018). Promoting or suppressing resilience to mental health outcomes in at risk young people: The role of parental and peer attachment and school connectedness. Journal of Adolescence, 64, 13 - 22. 
Parker, I. (2005). Qualitative psychology: Introducing radical research. New York: Open University Press. Retrieved from http://blogs.unpad.ac.id/teddykw/files/2012/08/QualitativePsychology.pdf Partington, G. (2001). Qualitative research interviews: Identifying problems in technique. Issues in Educational Research, 11(2), 32-44.

Parveen, S. (2008). An evaluative study of primary education in the light of policies and plans in Pakistan (1947 - 2006). Journal of College Teaching \& Learning, 5(7), 17-26.

Peshkin, A. (1963). The shaping of secondary education in Pakistan. History of Education Quarterly, 3(1), 4-18

Potter, J., \& Wetherell, M. (1987). Discourse and social psychology. London, UK: Sage Publications.

Rahman, T. (2006). Language policy, multilingualism and language vitality in Pakistan. In A.

Saxena \& L. Borin (Eds.), Trends in linguistic studies (pp. 73-105). New York, NY: Mouton de Gruyter.

Rehman, H., \& Khan, N. (2011). Flaws in Pakistan's educational system. Abasyn Journal of Social Sciences, 4(1), 70-83.

Saroglou, V. (2016). Intergroup conflict, religious fundamentalism and culture. Journal of Cross-Cultural Psychology, 47(1), 33-41.

Saumure, K., \& Given, L.M. (2008). Nonprobability sampling. In L. M. Given (Ed.), The sage encyclopedia of qualitative research methods (562). California: Sage Publications.

School outlaws Punjabi as foul language. (2016, October 13). Samaa.

Schunk, D.H., \&Meece, J. L. (2006). Self-efficacy development in adolescences. In T. U.

Pajares (Ed.), Self-efficacy beliefs of adolescents (71-96). Greenwich, CT: Information Age Publishing. 
Sewag, Z. (2016). The intra-sunni conflicts in Pakistan. In J. Syed, E. Pio, T. Kamran, \& A. Zaidi (Eds.), Faith-based violence and Deobandi militancy in Pakistan (pp. 313-344). London: Palgrave Macmillan.

Shah, J. (2012). Zia-ul-Haque and the proliferation of religion in Pakistan. International Journal of Business and Social Science, 3(21), 310-323.

Shah, M. N. (2014). Evolution of sectarianism in Pakistan: A threat to the state and society. A Research Journal of South Asian Studies, 29(2), 441-445.

Torrance,H(2010). Qualitative research methods in education. Sage Publication

Willig, C. (2008). Introducing qualitative research in psychology (2nd ed.). England: McGraw-Hill.

Winslade, J.M.(2005). Utilizing discursive positioning in counseling. British Journal of Guidance \& Counseling, 33(3),351-364.

\section{Citation of this Article}

Misri, A., \& Bilal, M. (2019). The discursive constructions in school: A qualitative assessment of value conflicts between school ethos and everyday life. Pakistan Journal of Education, 36(2), 1-22. 